\title{
RADIOGRAPHIC EVALUATION OF THE USE OF TRANSVERSE TRACTION DEVICE IN VERTEBRAL ARTHRODESIS FOR DEGENERATIVE DISEASES
}

\author{
AVALIAÇÃO RADIOGRÁFICA DO USO DO DISPOSITIVO DE TRAÇÃO TRANSVERSA NAS \\ ARTRODESES VERTEBRAIS DE PATOLOGIAS DEGENERATIVAS
}

\section{EVALUACIÓN RADIOGRÁFICA DE LA UTILIZACIÓN DEL DISPOSITIVO DE TRACCIÓN TRANSVERSAL EN LA ARTRODESIS VERTEBRAL PARA LAS ENFERMEDADES DEGENERATIVAS}

Edgar Takao Utino", João Paulo Machado Bergamaschi" ${ }^{1}$, Luciano Antonio Nassar Pellegrino ${ }^{1}$, Ricardo Shigueaki Galhego Umeta", Maria Fernanda Silber Caffaro ${ }^{1}$, Robert Meves ${ }^{1}$, Osmar Avanzi ${ }^{1}$

\begin{abstract}
Objective: Perform radiographic analysis of the use of Transverse Traction Device (DTT) with respect to fusion rate in patients submitted to vertebral arthrodesis for degenerative lumbar diseases. Methods: We selected x-ray images on anteroposterior, lateral and oblique views and with maximum flexion and extension dynamics of 23 patients submitted to posterolateral arthrodesis of the lumbar spine with a minimum follow-up period of six months. The images were evaluated and classified by the Linovitz's system by two spine surgeons. Results: We evaluated the radiographs of 23 patients after the minimum postoperative period of 6 months and of these, 11 have used DTT. With regard to the consolidation rate, seven patients (63.6\%) in the group of DTT were classified as fusion as well as six patients (50\%) who were not submitted to the treatment. There was no statistical difference between the groups regarding the consolidation rate. Conclusion: The use of transverse traction device in this study showed no significant difference in the rate of consolidation in radiographic evaluation. Studies on the effective participation of this device in the stability of pedicle fixation systems are still lacking in the literature.
\end{abstract}

Keywords: Spinal fusion; Surgical fixation devices; Spine.

\section{RESUMO}

Objetivo: Realizar análise radiográfica do uso do dispositivo de tração transversa (DTT) quanto a taxa de consolidação em pacientes submetidos à artrodese vertebral da coluna lombar em patologias degenerativas. Métodos: Foram selecionadas radiografias nas incidências anteroposterior, perfil, oblíquas e dinâmicas em flexão e extensão máxima de 23 pacientes submetidos à artrodese posterolateral da coluna lombar com seguimento pós-operatório mínimo de seis meses. As imagens foram avaliadas e classificadas pelo sistema de Linovitz, por dois cirurgiões de coluna. Resultados: Avaliamos as radiografias de 23 pacientes no pós-operatório mínimo de 6 meses sendo que destes, 11 fizeram uso do DTT. Quanto à taxa de consolidação foram classificados como fusão sete pacientes (63,6\%) no grupo que recebeu o DTT e seis pacientes (50\%) naqueles em que o dispositivo não foi utilizado. Não observamos diferença estatística entre os grupos quanto à taxa de consolidação. Conclusão: A utilização do dispositivo de tração transversa neste estudo não apresentou diferença significativa quanto à taxa de consolidação na avaliação radiográfica. Ainda faltam na literatura estudos sobre a efetiva participação deste dispositivo na estabilidade dos sistemas de fixação pedicular.

Descritores: Fusão vertebral; Dispositivos de fixação cirúrgica; Coluna vertebral.

\section{RESUMEN}

Objetivo: Análisis del uso del dispositivo de tracción transversal (DTT) respecto a la tasa de consolidación en las enfermedades degenerativas de la columna vertebral en pacientes sometidos a la artrodesis, a partir del estudio de los resultados radiológicos. Métodos: Se seleccionaron radiografías de la zona anteroposterior, oblicua y de perfil, así como, dinámicas de la flexión y extensión máxima, de 23 pacientes sometidos a la operación quirúrgica de artrodesis posterolateral de la columna lumbar, con un mínimo de seis meses después de la realización de la cirugía. Las imágenes fueron evaluadas y clasificadas mediante el sistema de Linovitz por dos cirujanos de columna. Resultados: Evaluamos las radiografías de 23 pacientes después de la cirugía, mínimo de seis meses después y en 11 de los 23 pacientes anteriormente mencionados, se usó DTT. En cuanto a la tasa de consolidación, siete pacientes (63,6\%) fueron clasificados como de fusión en el grupo con la DTT, así como seis pacientes (50\%) del grupo en el que no se utilizó el tratamiento. Por lo tanto, no se observó diferencia estadística entre los grupos respecto a la tasa de consolidación en el análisis radiográfico. Conclusiones: El uso del dispositivo de tracción transversal en este estudio no mostró diferencias significativas con respecto a la tasa de consolidación radiográfica. Además, no existen todavía estudios suficientes sobre la efectiva participación de este dispositivo en la estabilidad de los sistemas de fijación pedicular.

Descriptores: Fusión vertebral; Dispositivos de fijación quirúrgicos; Columna vertebral.

1. School of Medical Sciences, Santa Casa de São Paulo, São Paulo, SP, Brazil.

Study conducted at the Pavilhão Fernandinho Simonsen - Department of Orthopedics andTraumatology, Santa Casa de Misericórdia de São Paulo, São Paulo, SP, Brazil. Correspondence: Rua Dr. Cesário Mota Júnior, 112, Santa Cecília, São Paulo, SP, Brasil. 01277-900. edgar_utino@ @otmail.com 


\section{INTRODUCTION}

The use of pedicle screws as a system of spinal fixation is considered safe and effective in the treatment of diseases of the lumbosacral spine, and they have been widely used in the surgical treatment of various spinal diseases including trauma, tumors, degenerative diseases, and deformities. The emergence of these new fixation systems in the 1980s involved the development of new implants and instruments for the purpose of achieving greater mechanical stability. ${ }^{1}$

The use of the transverse (cross-link) stabilizer was initially described by Armstrong and Connock ${ }^{2}$ in 1970 for the correction of scoliosis with the Harrington instrumentation. Later, in 1984, Cotrel and Dubousset ${ }^{3}$ introduced the transverse traction device (TTD) in order to provide the system with greater stability and rotational correction.

Although it has been applied to increase the mechanical stability of the pedicle fixation systems, resulting in higher rates of bone union, its participation in the stabilization of these spinal fixation systems has not been made very clear. ${ }^{4-6}$

Through an experimental study, Dick et al. ${ }^{7}$ concluded that use of the TTD increased the stability of the system. Since then, various biomechanical experimental studies have emerged in the literature showing that use of the TTD provides an increase in stability, primarily in the torsional stability requirement in constructions with pedicle screws. ${ }^{7-12}$

In a mechanical test, Góes et al. ${ }^{10}$ demonstrated that the transverse stabilizer increases the mechanical stability of the internal fixator in the frontal plane and specially in the rotational plane, and that the use of two stabilizers provides greater rotational stability of the spinal fixation system.

Wahba et al. ${ }^{11}$ evaluated the biomechanical characteristics in short fixation with and without the TTD in human cadaveric models undergoing unstable burst fractures, and demonstrated that the addition of the TTD to posterior short fixation leads to increased stiffness and a reduction in axial rotation.

We must, however, consider that the effective participation of the device in the stability of the pedicle fixation systems remains uncertain according to the data available in the literature, which has prompted this study. The aim of the study was to evaluate the radiographic outcome of using the TTD in arthrodesis of degenerative diseases of the spine regarding rigid fixation, and the fusion rates of arthrodesis.

\section{METHODS}

This study is categorized as a retrospective case series.

The study was conducted at the Department of Orthopedics and Traumatology (Pavilhão Fernandinho Simonsen) of the Santa Casa de Misericórdia de São Paulo in the period from July to September 2011.

After the study was approved by the Ethics in Human Research Committee of the Irmandade da Santa Casa de Misericórdia de São Paulo, SP, Brazil, case number 191/11, the radiographs of the spines of patients were evaluated for spinal arthrodesis due to degenerative pathologies that made use of the TTD. All patients were treated and followed up by the Spine Group of the Department of Orthopedics and Traumatology, School of Medical Sciences, Santa Casa de Misericórdia de São Paulo. In each case, the radiographs were evaluated to identify the presence of rigid segmental fixation, the absence of signs of implant loosening, and the fusion rates.

The surgical approach was performed by means of a median approach, with the patient in the prone position under general anesthesia. All patients received an autologous cancellous bone graft along the transverse processes for the posterolateral arthrodesis and decompression by foraminotomy and laminectomy for the compromised roots. The intraoperative control for the introduction of pedicle screws was performed by fluoroscopy of the lumbosacral spine, front and profile, and the TTD was used in their respective populations.

Of the 23 patients in this series, 11 patients (48\%) used the TTD (Group 1), while 12 patients (52\%) did not (Group 2). The inclusion criteria were patients with degenerative lumbar disease undergoing surgical treatment for spinal arthrodesis and fixation with pedicle screws by a posterior approach (2 or 3 levels) with a minimal postoperative follow-up of six months and radiographs of good quality in the anteroposterior, profile, oblique and dynamic views (flexion and extension).

Data collection and radiographs were obtained from the medical records of the Department of Medical Records (SAME), Santa Casa de São Paulo, files from the Spine Surgery Group and during consultations in the Spine Surgery Outpatient Clinic, Department of Orthopedics and Traumatology (Pavilhão Fernandinho Simonsen) of the Santa Casa de Misericórdia de São Paulo.

Regarding sex, 17 patients were females and six were males. The arthrodesis of L4-S1 was carried out in 16 patients (70\%), of L3-L5 in three patients (13\%), of L1-L3 in one patient (4\%), and of L3-S1 (13\%) in three patients. (Table 1)

The mean age at surgery in Group 1 was 58 years, with a minimum of 45 years and a maximum of 76 years. In Group 2, it was 53 years, with a minimum of 35 years and a maximum of 79 years. Patients in Group 1 had a mean postoperative follow-up of 16 months, with a minimum of six months and a maximum of 33 months. The patients in Group 2 had a mean postoperative followup of 15 months, with a minimum of ten months and a maximum of 24 months. (Table 2)

To characterize the population regarding the radiographic assessment of fusion rates of the arthrodesis, the Linovitz radiographic

Table 1. Descriptive analysis of categorical variables by group.

\begin{tabular}{c|c|c|c|c}
\hline \multirow{2}{*}{ Variables by group } & \multicolumn{2}{|c|}{ Group 1 } & \multicolumn{2}{c}{ Group 2 } \\
\cline { 2 - 6 } & Total & (\%) & Total & (\%) \\
\hline Observation (Levels of arthrodesis) & & & & \\
\hline Decompression and arthrodesis L1-L3 (2 levels) & 0 & $(0.0)$ & 1 & $(8.3)$ \\
\hline Decompression and arthrodesis L3-L5 (2 levels) & 1 & $(9.1)$ & 2 & $(16.7)$ \\
\hline Decompression and arthrodesis L3-S1 (3 levels) & 2 & $(18.2)$ & 1 & $(8.3)$ \\
\hline Decompression and arthrodesis L4-S1 (2 levels) & 8 & $(72.7)$ & 8 & $(66.7)$ \\
\hline Sex & & & & \\
\hline Female & 9 & $(81.8)$ & 8 & $(66.7)$ \\
\hline Male & 2 & $(18.2)$ & 4 & $(33.3)$ \\
\hline
\end{tabular}

Source: SAME-ISCMSP

Table 2. Descriptive analysis of numerical variables by group.

\begin{tabular}{c|c|c|c|c}
\hline \multirow{2}{*}{ Variables by group } & \multicolumn{2}{|c|}{ Age } & \multicolumn{2}{c}{$\begin{array}{c}\text { Postoperative time in } \\
\text { months }\end{array}$} \\
\cline { 2 - 5 } & Group 1 & Group 2 & Group 1 & Group 2 \\
\hline Mean & 58.4 & 53.3 & 16.3 & 15.2 \\
\hline Minimum & 45.0 & 35.0 & 6.0 & 10.0 \\
\hline Maximum & 76.0 & 79.0 & 33.0 & 24.0 \\
\hline
\end{tabular}


classification was used. (Appendix 1) The review was performed by two spine surgeons properly trained to perform the task, which recorded from the analysis of good quality radiographs in the anteroposterior, profile, oblique and dynamic views.

The Linovitz classification consists of four grades, being Grade 0 (No Fusion), Grade I (Minimal Fusion), Grade II (Moderate Fusion) and Grade III (Solid Fusion). ${ }^{13}$

Once the data were collected, the scales were made compatible to simplify the statistical analysis, classifying patients as lack of fusion (Grade 0 and I) or presence of fusion (Grade II and III).

To compare the variable of consolidation between the two surgical procedures, lumbar fusion surgery with a posterior approach with the use of the TTD (Group 1) and surgery without the use of the device (Group 2), the Fisher's exact test was used. A significance level of $5 \%$ was used ( $p$ value $\leq 0.05$ ).

\section{RESULTS}

In Group 1, one patient was classified as grade 0, three as grade I, six as grade II, and one as grade III. In Group 2, two were classified as grade 0 , four as grade I, five as grade II, and one as grade III. (Figure 1A-F - Case 1)

In Group 1, four patients were classified as "no fusion" and seven as "fusion." In Group 2, six were classified as "fusion" and six as "no fusion." (Table 3)

According to the results in Table 3, there was no significant difference between groups regarding the rate of consolidation.
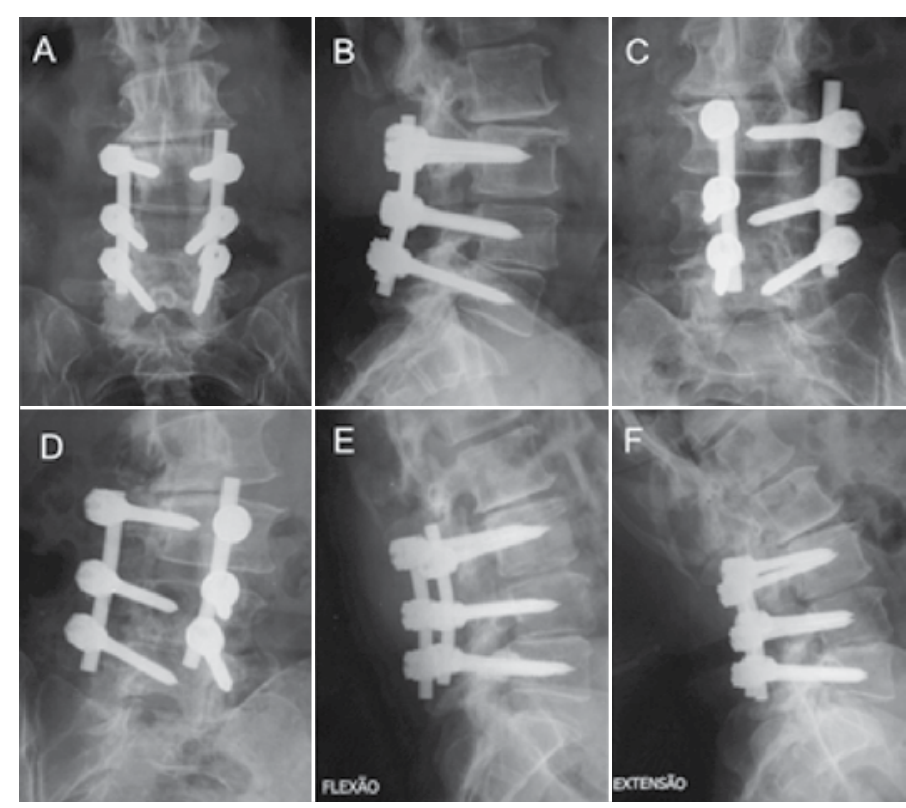

Figure 1. Case 1: (A and B) AP and lateral radiographs at 1 year postoperatively, showing the positions of the pedicle screws at L3, L4, and L5, with no signs of loosening of the material, $(C$ and $D)$ radiographs in oblique view showing the consolidation of the arthrodesis (Classified as Linovitz Grade II), (E and F) dynamic radiographs showing no movement.

\section{DISCUSSION}

The use of a transverse traction device was initially used in surgery for scoliosis correction, and improved the system stability. Currently, these devices are routinely used components for connecting the longitudinal rods to the pedicle fixation systems in order to improve their mechanical stability, especially to torsional forces. ${ }^{8}$

Clinical and experimental investigations have indicated that an increase in the mechanical stability of the systems accelerates bone healing and decreases the rate of pseudarthrosis. ${ }^{4,8}$ Thus, we conducted this study in order to indirectly observe whether the use
Table 3. Descriptive analysis of categorical variables by group and the outcome of the tests applied.

\begin{tabular}{|c|c|c|c|c|c|}
\hline \multirow{2}{*}{ Variables by group } & \multicolumn{2}{|c|}{ Group 1} & \multicolumn{2}{|c|}{ Group 2} & \multirow{2}{*}{$p$ value } \\
\hline & Total & $(\%)$ & Total & $(\%)$ & \\
\hline \multicolumn{6}{|c|}{ Consolidation (Linovitz grade) } \\
\hline Grade 0 & 1 & (9.1) & 2 & $(16.7)$ & \multirow{4}{*}{ - } \\
\hline Grade I & 3 & (27.3) & 4 & (33.3) & \\
\hline Grade II & 6 & $(54.5)$ & 5 & $(41.7)$ & \\
\hline Grade III & 1 & (9.1) & 1 & (8.3) & \\
\hline \multicolumn{6}{|l|}{ Grouped consolidation ${ }^{1}$} \\
\hline No fusion & 4 & (36.4) & 6 & $(50.0)$ & \multirow{2}{*}{0.680} \\
\hline Fusion & 7 & $(63.6)$ & 6 & $(50.0)$ & \\
\hline
\end{tabular}

1: $p$ value of Fisher's exact test.

of this device resulted in a better consolidation rate through the radiographic analysis of the consolidation rate achieved between the different groups with and without the use of a transverse traction device in a pedicle fixation system.

There is no consensus in the literature as how to best analyze and classify the fusion rate. There are many imaging methods to analyze and classify the rate of spinal fusion. The simplest, most low-cost, and probably the most widely used is still plain radiography. However, its accuracy has been reported to be between $60-70 \%$.

In this study, we used the Linovitz classification to assess the rate of consolidation on radiographs between different groups because it is a classification that is easy to apply, and it has good objectivity in its interpretation. ${ }^{13}$

Another important point to be discussed is that the radiographic finding is not always consistent with the findings of surgical exploration. Surgical exploration is the gold standard for identifying bone fusion. Comparative analyses between the radiographic findings and intraoperative in vivo findings suggest that in up to $20 \%$ of cases, the radiographic findings underestimate the grade of fusion in relation to the findings in surgical exploration, similar to those found in our study. ${ }^{14-16}$

During the analysis of the radiographic classification, we confirmed the difficulty in observing in the radiographs an image of integration of the solid graft and continuous in the region of the transverse process of the vertebrae which is consistent with the results observed in this study.

\section{CONCLUSION}

Radiographic evaluation of the use of the transverse traction device (TTD) in vertebral arthrodesis for degenerative diseases showed no significant differences in the rate of consolidation.

The literature is still scarce in studies on the effective participation of the device in the stability of the pedicle fixation systems, requiring further investigation.

All authors declare no potential conflict of interest concerning this article. 


\section{REFERENCES}

1. Gaines RW Jr. The use of pedicle-screw internal fixation for the operative treatment of spinal disorders. J Bone Joint Surg Am. 2000;82(10):1458-76.

2. Armstrong GW, Connock SH. A transverse loading system applied to a modified Harrington instrumentation. Clin Orthop Relat Res. 1975;(108):70-5.

3. Cotrel Y, Dubousset J. [A new technic for segmental spinal osteosynthesis using the posterior approach]. Rev Chir Orthop Reparatrice Appar Mot. 1984;70(6):489-94.

4. Defino HL, Moro CA, Fuentes ER, Paulin JB. Avaliação da angulação dos parafusos e utilização do estabilizador transversal na estabilidade do sistema de fixação pedicular. Rev Bras Ortop. 1996;31(11):925-30.

5. Hart R, HettwerW, Liu Q, Prem S. Mechanical stiffness of segmental versus nonsegmental pedicle screw constructs: the effect of cross-links. Spine (Phila Pa 1976). 2006:31(2):E35-8.

6. Burney MU, Mukherjee DP, Ogden AL, Robinson E, McCall RE. A biomechanical study of posterior spinal instrumentation using pedicle screws with and without cross-links. J Spinal Disord Tech. 2005;18(4):364-8.

7. Dick JC, Jones MP, ZdeblickTA, Kunz DN, Horton WC. A biomechanical comparison evaluating the use of intermediate screws and cross-linkage in lumbar pedicle fixation. J Spinal Disord. 1994;7(5):402-7.

8. Dick JC, ZdeblickTA, Bartel BD, Kunz DN. Mechanical evaluation of cross-link designs in rigid pedicle screw systems. Spine (Phila Pa 1976). 1997:22(4):370-5.

9. Lynn G, Mukherjee DP, Kruse RN, Sadasivan KK, Albright JA. Mechanical stability of thoracolumbar pedicle screw fixation. The effect of crosslinks. Spine (Phila Pa 1976). 1997;22(14):1568-72.
10. Goes AL, Shimano AC, Defino HL. Estudo biomecânico da participação do estabilizador transversal na estabilidade mecânica das fixações vertebrais com o fixador interno. Coluna/Columna 2004;3(3):122-7.

11. Wahba GM, Bhatia N, Bui CN, Lee KH, Lee TQ. Biomechanical evaluation of short-segment posterior instrumentation with and without crosslinks in a human cadaveric unstable thoracolumbar burst fracture model. Spine (Phila Pa 1976). 2010;35(3):278-85

12. Brodke DS, Bachus KN, Mohr RA, Nguyen BK. Segmental pedicle screw fixation or cross-links in multilevel lumbar constructs. a biomechanical analysis. Spine J. $2001 ; 1(5): 373-9$

13. Linovitz RJ, Pathria M, Bernhardt M, Green D, Law MD, McGuire RA, et al. Combined magnetic fields accelerate and increase spine fusion: a double-blind, randomized, placebo controlled study. Spine (Phila Pa 1976). 2002;27(13):1383-9;

14. Rodrigues DG, Coelho JA, Oliveira CE, Sontoro AG, Trindade RM, Pereira SA. Análise da Reprodutibilidade intra e inter-observadores das classificações radiográficas para avaliação da artrodese da coluna lombar. Coluna/Columna 2008;7(3):257-61.

15. Kant AP, Daum WJ, Dean SM, Uchida T. Evaluation of lumbar spine fusion. Plain radiographs versus direct surgical exploration and observation. Spine (Phila Pa 1976). 1995;20(21):2313-7.

16. Blumenthal SL, Gill K. Can lumbar spine radiographs accurately determine fusion in postoperative patients? Correlation of routine radiographs with a second surgical look at lumbar fusions. Spine (Phila Pa 1976). 1993;18(9):1186-9.

Appendix 1. Linovitz classification.

\begin{tabular}{|c|c|c|c|c|}
\hline Grade & Category & Continuity percentage & Movement & Description \\
\hline 0 & No Fusion & 0 to $<25$ & Present & Discontinuity of the fusion mass with movement \\
\hline$I$ & Minimal Fusion & 25 to $<50$ & Present & Slight discontinuity of the fusion mass with movement \\
\hline II & Moderate Fusion & 50 to $<75$ & Absent & Continuity of the fusion without movement \\
\hline III & Solid Fusion & 75 to 100 & Absent & Extensive fusion without movement \\
\hline
\end{tabular}

